\title{
The consequences of Brazil's lack of transport planning is written in the blood of sparrows
}

Article

Accepted Version

Angeoletto, F., Leandro, D. d. S. and Fellowes, M. D. E. (2019) The consequences of Brazil's lack of transport planning is written in the blood of sparrows. Urban Geography, 40 (8). pp. 1191-1197. ISSN 1938-2847 doi:

https://doi.org/10.1080/02723638.2019.1653135 Available at https://centaur.reading.ac.uk/85541/

It is advisable to refer to the publisher's version if you intend to cite from the work. See Guidance on citing.

To link to this article DOI: http://dx.doi.org/10.1080/02723638.2019.1653135

Publisher: Taylor and Francis

All outputs in CentAUR are protected by Intellectual Property Rights law, including copyright law. Copyright and IPR is retained by the creators or other copyright holders. Terms and conditions for use of this material are defined in the End User Agreement.

www.reading.ac.uk/centaur 
Central Archive at the University of Reading

Reading's research outputs online 
The consequences of Brazil's lack of transport planning is written in the blood of sparrows.

Fabio Angeoletto

Deleon da Silva

Fabio Angeoletto ${ }^{1}$, Deleon da Silva Leandro ${ }^{1}$ and Mark D. E. Fellowes ${ }^{2}$

1Programa de Pós-Graduação em Geografia da Universidade Federal de Mato Grosso, Rodovia, Rondonópolis/Guiratinga, Brazil

${ }^{2}$ People and Wildlife Research Group, School of Biological Sciences, University of Reading, Reading, UK

\section{Abstract}

The medium-sized cities of Brazil are those with populations of between 100,000 and 500,000 inhabitants. These cities are growing rapidly, and are characterized by poor urban planning, a loss of biodiversity and decreasing health prospects for residents. Historically, urbanization in Brazil has been associated with incentives to increase the use of private vehicles for local transport. The air pollution resulting from this "car dependency" has been quantified in some major cities in Brazil, such as the megacity of São Paulo. In this paper, we demonstrate through a bioindication study (using the House Sparrow Passer domesticus) carried out in the Brazilian city of Rondonópolis, that atmospheric pollution resulting from vehicular emissions is also a measurable reality for medium-sized cities. Most Brazilian cities lack air quality measurement equipment, and we used an inexpensive, simple, and easy to apply bioindication assay to measure air pollution, and this approach could be easily implemented in those cities and beyond. Effective management of air quality in Brazil's medium-sized cities and beyond is essential if we are to support urban biodiversity and to reduce the impacts of pollution on human health.

Keywords: Medium-sized cities of Brazil, bioindicators of air pollution, vehicular emissions, urban ecology, urban biodiversity, urban health and well-being 
Today, $85 \%$ of Brazilians live in cities. In the first wave of urbanization, migrants moved to the big cities, which rapidly expanded. Since the mid-1990s, there has been a second wave of urbanization, with a substantial increase in the number of medium-sized cities (with populations of between 100,000 and 500,000 inhabitants), their human population size, and area they occupy. In this time period, the total area occupied by large metropolises has decreased, while the area occupied by medium-sized cities has quickly grown, increasing from $11.77 \%$ (1970) to $27.23 \%$ (2000) of the total area occupied by Brazilian cities. The number of medium-sized cities has also increased considerably over the period, from 40 in 1970 to 194 in 2000 (CARVALHO, 2003). Today, there are 264 medium-sized cities in Brazil, in which approximately 52 million people live, some 25\% of the national population. These rapidly growing cities share one unfortunate feature, a shared low level of urban management and planning (ANGEOLETTO et al 2016).

Historically, the hegemony of individual urban transportation, where people travel in private vehicles, was built into the foundations of the 1934 Brazilian Constitution, which directed highway construction efforts in the country. In 1956, the Brazilian automobile industry began, and this was followed by public policies to support motor vehicles, particularly private cars and motorcycles. This is because successive Brazilian governments prioritized and subsidized the automobile industry, which led to the marginalization and dismantling of less polluting modes of transport, such as urban railways (Rubin \& Leitão, 2013).

The low priority accorded to public transportation in Brazilian cities lasted through the $20^{\text {th }}$ century and continues into the $21^{\text {st }}$. Between 2005 and 2015, the number of automobiles in Brazil grew by $138 \%$, while the Brazilian population expanded by just $12.2 \%$. As an case in point, consider Rondonópolis, a medium-sized city and an important national hub for Brazilian agribusiness. In the same period, the private vehicle fleet in Rondonópolis leapt from just over 57,000 vehicles to 155,796 vehicles (an increase of $171 \%$ ), while the population grew by only $25 \%$ (from 172,000 to 215,000 inhabitants) (LEANDRO, 2017).

The reduction of the IPI (Imposto sobre Produtos Industrializados, Tax on Industrialized Products) rate for automobiles is an example of the low priority accorded to public transportation (CNT and NTU, 2017), and was one of the measures adopted to avoid the recessionary trend caused by the global financial crisis of 2008. There were two reductions: the first of December of 2008 to March of 2010 and then from May 2012 to December 2014. These "car-dependency" incentives granted during the governments of presidents Lula da Silva and Dilma Rousseff, both of the Workers' Party (PT, Partido dos 
Trabalhadores), underscores two points. First, the environmental agenda was never a priority for any government in Brazil, regardless of its political ideology. The social and environmental consequences of these decisions, which resulted in a rapid increase in the numbers of private vehicles, were not considered. These changes also have financial impacts, such as the higher incidence of respiratory diseases caused by the increase in vehicular emissions of air pollutants (MIRANDA et al 2012; ANGEOLETTO et al 2016; LEANDRO, 2017). Second, the "car-dependency" of Brazilian cities has never been adequately addressed by national, state or municipal legislative powers (VIANNA et al 2004; BARBOSA et al 2017). On the contrary, in Brazil, for each Real (the Brazilian monetary unit) invested by the State in public transportation (e.g. acquisitions of bus fleets or construction of infrastructure for subway lines), eight are invested in individual transportation (through, for example, the construction of new roads, largely for the growth in private vehicles; VASCONCELOS, 2014). Moreover, public transportation systems have many problems and the quality of service provided is low. Therefore this is a strong incentive for Brazilian citizens to acquire private vehicles; today there is around 91 million units, of which 52 million (57\%) are privately-owned vehicles in Brazil, for a population of circa 200 million people (BARBOSA et al 2017; CNT and NTU, 2017).

Public transportation systems always had low priority in the three Brazilian spheres of governance (municipal, state and national). On the other hand the National Policy on Urban Mobility (PNMU), instituted by Federal Law 12.587/2012, was an initiative to mitigate the excessive dependence on private vehicles in Brazilian cities. The law provides for incentives to increase the number of non-motorized journeys (on foot or by bicycle, for example), the prioritization of collective transportation, and discourages the use of private automobiles and motorcycles. The PNMU also directs that all Brazilian municipalities with more than 20,000 inhabitants must prepare an Urban Mobility Plan. This group covers 1768 municipalities, where about 176 million Brazilians live - some $85 \%$ of the country's population. However, by May 2018, only 171 cities ( $9 \%$ of the total) had responded. These 171 cities are home to $25 \%$ of the Brazilian population (MINISTÉRIO DAS CIDADES, 2018). The implementation of the PNMU, seven years after its promulgation, remains limited.

The list of socio-environmental impacts caused by relying upon a model of transport based on private vehicles is extensive and well characterised. These local consequences range from the economic costs of traffic jams to significant public health issues resulting from vehicular pollution. In Brazilian cities, urban private transportation (trips by people in private cars and motorcycles) emits 4.9 times more local pollutants and 1.8 times the volume of CO2 than the public transport system (MINISTÉRIO DAS CIDADES, 2016), 
despite the fact that vehicles used in public transportation systems carry $76.7 \%$ of passengers, while private vehicles carry only $20.6 \%$ of people. Consequently, in urban Brazil, vehicle emissions are the main source of pollution (e.g. fine particulate matter; PM2.5) (MIRANDA et al., 2012; PEREZ-MARTINEZ et al 2014; AMATO-LOURENÇO et al 2016).

We performed a bioindication study of atmospheric pollution in urban Rondonópolis, based on methodology proposed by Herrera-Dueñas et al (2014). We captured house sparrows (Passer domesticus) at three points with the most intense flows of vehicles, with the aim of extracting blood samples and measuring morphophysiological parameters. The domestic sparrow (Passer domesticus L.) is sedentary (its territory reaches a few tens of meters) and closely associated with urban environments, characteristics that make them an ideal species for the biomonitoring of urban atmospheric pollutants (HERRERA-DUEÑAS et al. 2014). Addiitonally, collecting blood samples from house sparrows, rather than from the human residents of Rondonopolis, is legally and ethically much more straight-forward. Birds were released after collection of blood samples. Blood samples were compared with samples collected at a control point, a green area with low vehicle flow. While correlation does not guarantee causation, we collected the blood samples at points where the only close sources of pollutants were motor vehicles, rather than from other (e.g. industrial) sources.

Birds captured at all points with intense flow of vehicles presented morphophysiological changes. For example, Highway BR-364 (Figure 1) cuts through urban Rondonópolis, and demonstrates the poor quality of urban planning and management in Brazilian cities. There is a daily traffic of 26,000 vehicles on the portion of the highway that crosses the urban area of Rondonópolis, (LEANDRO, 2017). House sparrows captured in the Vila Salmen neighborhood, an urban area of extreme poverty along Highway BR-364, had on average $24 \%$ more hemoglobin (the $\mathrm{O}_{2}$ carrier protein) and almost $50 \%$ more heterophils (defense cells) than birds captured at the control point. These physiological changes - clear indicators of air pollution (HERRERA-DUEÑAS et al 2014) - occur because hemoglobin also chemically binds with $\mathrm{CO}_{2}$, losing its ability to carry oxygen. Abnormally high levels of $\mathrm{CO}_{2}$ cause an increase in hemoglobin production, as the birds physiologically compensate for the effects of the pollutant in the air. Similarly, heterophil counts increase as a physiological reaction to the elevated levels of airborne Particulate Material (mainly $\mathrm{PM}^{2,5}$ ). Heterophils act to assimilate pollutants that have been absorbed by the body through respiration (LEANDRO, 2017). 


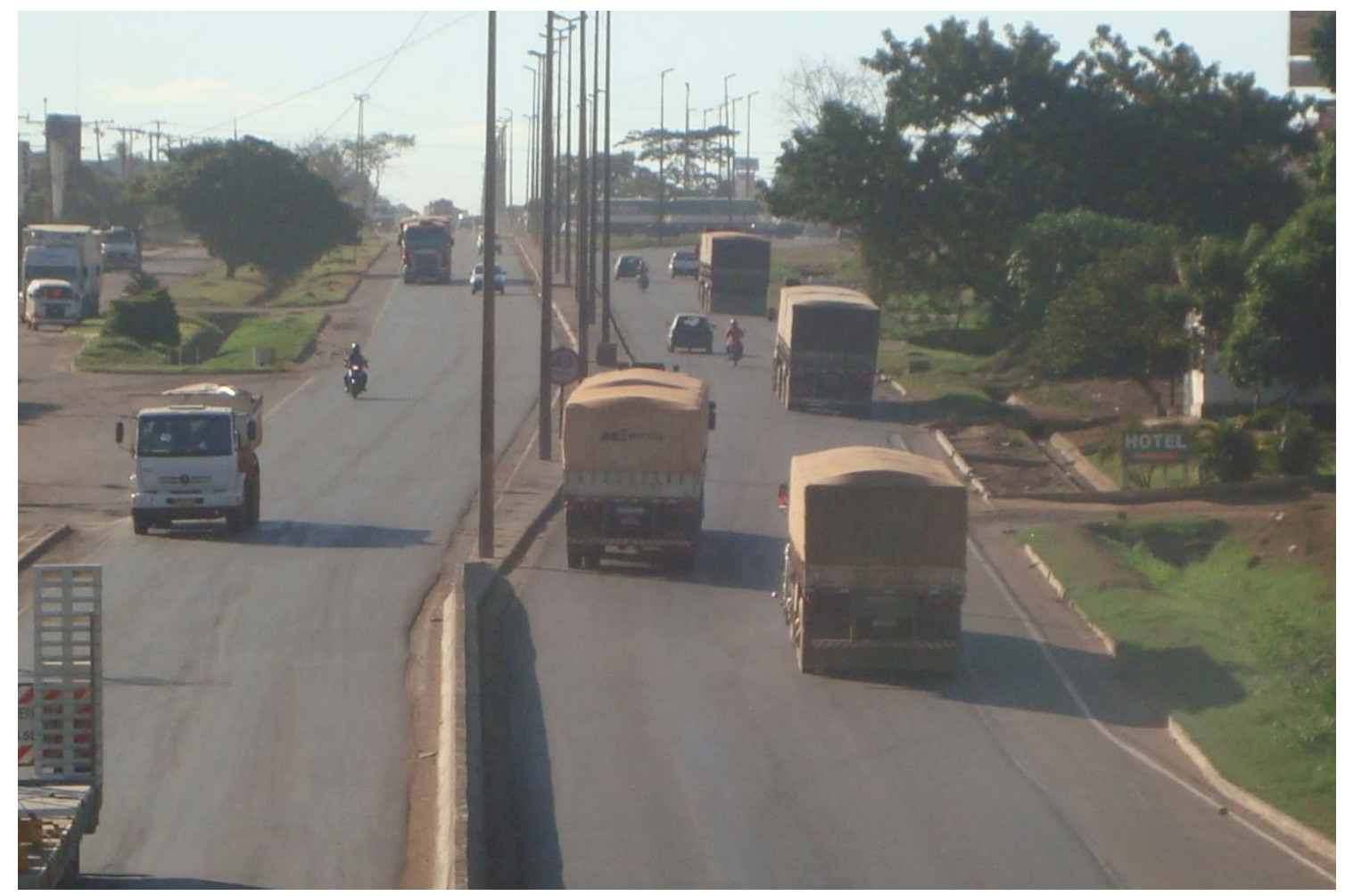

Figure 1. In Rondonópolis, as in other medium-sized Brazilian cities, the lack of urban planning increases the flow of vehicles, which degrades air quality.

The house sparrows in this study showed clear evidence of significant physiological changes in response to vehicular air pollution. Only $11 \%$ of Brazil's medium-sized cities have air quality monitoring stations (ANGEOLETTO et al 2016), and the methodology of biomonitoring using $P$. domesticus blood samples shows the effects of what is going unrecorded. House sparrows occur in practically every city in Brazil, and municipal governments could easily use them for periodic air quality biomonitoring.

This study demonstrates that harmful air pollution is not limited to megalopolises such as São Paulo. Rondonópolis, because of national and local transport policies, faces what appears to be an intractable challenge of creating alternative ways to improve its air quality. Air pollution will not only affect house sparrows, but will also have deleterious effects on flora, on the people and on the wild species that inhabit or move through the city's urban area (Dods et al., 2005; RAl, 2016; González-Lagos \& Quesada, 2017).

Despite pollution from vehicles, nature persists in the city. A recent survey recorded 127 species of birds in Rondonópolis. This is $15 \%$ of the avifauna of the Cerrado Biome, a global biodiversity hotspot, in which the municipality is embedded. The advanced and 
accelerating devastation of the Cerrado megadiversity (SILVA et al., 2017; VACCHIANO et al. 2018) is a clear indication that the usual approach of creating pristine protected areas for the conservation of biodiversity is insufficient. Cities also need to be thought of as potential spaces for the conservation of biological diversity, and this is particularly important for cities located in biodiversity hotspots. Rondonópolis and cities around the world need to be studied from an urban ecological approach from both social and natural science perspectives. These studies should aim to produce insights that disentangles the socio-environmental complexity of urban landscapes (RUMBLE et al. 2019). Such understanding has immense relevance for urban planning, allowing cities to develop in ways that benefits both people and nature.

Cities are complex ecological systems that are under environmental, social, economic, political and cultural influences. Brazilian cities are a powerful example of this plurality of influences. Providing Brazilian cities with public transportation is only a step in the fight against our addiction to fossil fuels. A coherent, integrated policy which supports the use of less polluting public transportation is essential. Incentives to use other modes of transportation is one such policy. For example, the construction of bike paths in residential areas, associated with subway stations, has increased the use of bicycles in Brazilian cities (FLORINDO et al 2018).

Urbanization will continue to be one of the most globally significant drivers of human impact on biodiversity, unless there are profound changes in land use policies and planning (Rumble et al. 2019). In turn, the preservation of biodiversity feeds an increase in the quality of human life in cities (ANGEOLETTO et al. 2018). The preservation of biodiversity, not only on a regional or a global scale, but also on a local scale, is an indispensable prerequisite for us to achieve decent living standards in cities.

Brazil has the greatest biological wealth of the planet (Mittermeier et al 1997), and the capacity of its 5570 cities to develop with reduced environmental impacts will in large part determine the success or failure of attempts to conserve its megadiversity. Can we build a future where the owning of a combustion-engined vehicle is not seen as a social norm, and where we integrate urban greening approaches to mitigate vehicular damage? If not, the foreseeable future of Brazilian cities is one of gridlock, public ill health and biodiversity loss. Given where we are we cannot hope for a return to some past green utopia, but we must fight to avoid the dystopian future visible on the horizon. . 


\section{REFERENCES}

Amato-Lourenco, L. F., Moreira, T. C. L., de Oliveira Souza, V. C., Barbosa Jr, F., Saiki, M., Saldiva, P. H. N., \& Mauad, T. (2016). The influence of atmospheric particles on the elemental content of vegetables in urban gardens of Sao Paulo, Brazil. Environmental pollution, 216, 125-134.

Angeoletto, Fabio, Santos, Jeater W. M. C., Sanz, Juan P. R., da Silva, Frederico F., \& Albertín, Ricardo. M. (2016). Tipología socio-ambiental de las ciudades medias de Brasil: aportes para un desarrollo urbano sostenible. Urbe. Revista Brasileira de Gestão Urbana, 8(2), 272-287.

Angeoletto, F., Fellowes, M. D.E., \& Santos, J. W. (2018). Counting Brazil's Urban Trees Will Help Make Brazil's Urban Trees Count. Journal of Forestry, 116(5), 489490.Barbosa, S. B., Ferreira, M. G. G., Nickel, E. M., Cruz, J. A., Forcellini, F. A., Garcia, J., \& de Andrade, J. B. S. O. (2017). Multi-criteria analysis model to evaluate transport systems: An application in Florianópolis, Brazil. Transportation Research Part A: Policy and Practice, 96, 1-13.

Carvalho, E. 2003. Exclusao social e crescimento das cidades medias brasileiras.

Scripta Nova - Revista Electrônica de Geografía y Ciencias Sociales 6(146).

CNT [Confederação Nacional de Transporte]; NTU (Associação Nacional de Empresas de Transporte Público) (2017). Pesquisa mobilidade da população urbana 2017. Brasília,, 96 p..

Dods, P. L., Birmingham, E. M., Williams, T. D., Ikonomou, M. G., Bennie, D. T., \& Elliott, J. E. (2005). Reproductive success and contaminants in tree swallows (Tachycineta bicolor) breeding at a wastewater treatment plant. Environmental toxicology and chemistry, 24(12), 3106-3112.Florindo, A., Barrozo, L., Turrell, G., Barbosa, J., CabralMiranda, W., Cesar, C., \& Goldbaum, M. (2018). Cycling for transportation in Sao Paulo City: associations with bike paths, train and subway stations. International journal of environmental research and public health, 15(4), 562.

González-Lagos, C., \& Quesada, J. (2017). Stay or Leave? Avian Behavioral Responses to Urbanization in Latin America. In MacGregor-Fors, I.; Escobar-lbañez, JF (editors). Avian Ecology in Latin American Cityscapes (pp. 99-123). Springer, Cham.

Herrera-Duenas, Amparo, Pineda, Javier, Antonio, Maria T., \& Aguirre, José I. (2014). Oxidative stress of house sparrow as bioindicator of urban pollution. Ecological Indicators, 42, 6-9. 
Ministério das Cidades (2016). Indicadores de Efetividade da Política Nacional de Mobilidade Urbana. Brasília: Imprensa Oficial do Governo Federal. 112 páginas.

Miranda, Regina M., de Fatima Andrade, Maria, Fornaro, Adalgiza, Astolfo, Rosana, de Andre, Paulo A., \& Saldiva, Paulo (2012). Urban air pollution: a representative survey of PM2. 5 mass concentrations in six Brazilian cities. Air quality, atmosphere \& health, 5(1), 63-77.

Pérez-Martínez, Pedro J., Miranda, Regina. M., Nogueira, Timóteo., Guardani, Marcos. L., Fornaro, Adalgiza, Ynoue, Robert., \& Andrade, Maria. F. (2014). Emission factors of air pollutants from vehicles measured inside road tunnels in São Paulo: case study comparison. International Journal of Environmental Science and Technology, 11(8), 2155-2168.

Rai, P. K. (2016). Biodiversity of roadside plants and their response to air pollution in an Indo-Burma hotspot region: implications for urban ecosystem restoration. Journal of Asia-Pacific Biodiversity, 9(1), 47-55.

Rubim, Barbara, \& Leitão, Sérgio (2013). O plano de mobilidade urbana e o futuro das cidades. Estudos Avançados, 27(79), 55-66.

Rumble, H., Angeoletto, F., Connop, S., Goddard, M. A., \& Nash, C. (2019). Understanding and applying ecological principles in cities. In de Oliveira, F. L., \& Mell, I. (Eds.). (2019). Planning Cities with Nature: Theories, Strategies and Methods. Springer.

Ministério das Cidades (2018). Levantamento sobre a situação dos Planos de Mobilidade Urbana nos municípios brasileiros. Retrieved from http://www.cidades.gov.br/component/content/article?id=4398

Mittermeier, Russel; Mittermeier, Cristina Gil, Patricio; Wilson, E.O. Megadiversity: Earth's Biologically Wealthiest Nations(CEMEX, 1997).

Silva, Normandes M., Angeoletto, Fabio, Santos, Jeater W., Paranhos Filho, Antonio, Vacchiano, Marcelo C., Bohrer, João F., \& Cândido, Anny K. A. (2017). The negative influences of the new brazilian forest code on the conservation of riparian forests. European Journal of Ecology, 3(2), 116-122.

Vacchiano, M. C., Santos, J. W., Angeoletto, F., \& Silva, N. M. (2019). Do Data Support Claims That Brazil Leads the World in Environmental Preservation?. Environmental Conservation, 46(2), 118-120. 
Vasconcellos, Eduardo A. (2014). Urban Transport Environment and Equity: The case for developing countries. Routledge.

WHO (2015). Global status report on road safety. WHO Press. Switzerland: 340 p. 